\title{
Preliminary Characterization of some Fig Biotypes in Romania
}

\author{
Holia AHMAD ${ }^{1}$, Florin STĂNICĂ ${ }^{1}$, Mohammed Mehdi AL MASOODY², Ana Cornelia BUTCARU ${ }^{1 *}$ \\ ${ }^{1}$ University of Agronomic Sciences and Veterinary Medicine, 59 Mărăști Boulevard, București 011464, \\ Romania \\ ${ }^{2}$ AL-Musiab Technical College, AL-Furat AL-Awsat Technical University, Iraq \\ *Corresponding author, e-mail: anabutcaru@gmail.com
}

Bulletin UASVM Horticulture 74(2)/ 2017

Print ISSN 1843-5254, Electronic ISSN 1843-5394

DOI:10.15835/buasvmcn-hort: 0024

\begin{abstract}
Fig (Ficus carica L.) is an antique fruit species originated from Asia and spread all over the world. In Romania, many genotypes are found on mild climate zones, being cultivated in small gardens as ornamental and fruit plant. At the Bucharest Faculty of Horticulture recently, fig genotypes have been collected from different places, propagated and studied. This paper presents the first results regarding the characterization of some fig genotypes found in different areas of Romania. An Iraqian fig genotype was also characterized. On medium term, the team aims to identify local grown fig plants, to establish a fig distribution wide map in Romania and to analyse different plants parameters in order to decide the best genotypes to be planted in the future. Cuttings from different figs genotypes and different regions of Romania and Iraq were collected and rooted. After planting in pots, the new obtained plants where grown under controlled conditions for a year. By using the mother plants and/or the new propagated plants, several measurements and determinations were done in order to characterize each genotype. Leaves were studied and measured with Win Folia scanner and software, while fruits were observed, measured and total soluble solids was determined by refractometer. The collected biotypes are planted in four testing plots in different regions in Romania.
\end{abstract}

Keywords: Ficus carica, fruits, leaves

\section{INTRODUCTION}

The edible fig (Ficus carica L.) is an antique fruit species originated from Asia well known before wheat and frequently mentioned in the Bible and Koran. Egyptians, Persians, Greeks, Romans, Muslims, Jews were ancient peoples who very much appreciated fig fruits.

Fig belongs to Moraceae Family and has many cultivated varieties since historical times. Fig tree can reach $4 \mathrm{~m}$ high, has smooth light grey bark, thick branches and very large falling leaves, dark green coloured, with toothed and irregular edges.

Flowers are grouped in beautiful inflorescences and are pollinated by wasps. The fruits are large, round or pear shape, covered with a fairly thin skin, and can weight even more than 30-40 g. There are several coloured types of figs: violet, yellow and white. (Stănică et al., 2003; Hoza, 2001)

The fruit has many nutraceutical properties and is usually consumed fresh or dried. There are several figs made products as jams, paste confection, canned foods, fruits in syrup, wine, juice, liquor etc. (Stănică et al., 2011; Ghena et al., 2010; Hoza, 2000).

Despite its varietal diversity, fresh fig is still considered a minor fruit in the Mediterranean countries trade. (Bandelj Mavsar et al., 2008).

In Romania, many genotypes are found on mild climate zones, being cultivated in small gardens as 
Tab. 1. Fig (Ficus carica) genotypes and their locations

\begin{tabular}{ccc}
\hline No & Genotype & Origin \\
\hline V1 & Secuilor 1 & București, România \\
\hline V2 & Secuilor 2 & București, România \\
\hline V3 & Negoiești 01 & Prahova, România \\
\hline V4 & Str. Ștefan cel Mare & București, România \\
\hline V5 & Muzeul Storck & București, România \\
\hline V9 & Sebus & Oradea, România \\
\hline V10 & Stoica Dan & Mangalia, România \\
\hline V11 & Galben mare Giurgiu (Braniștea G.) & Giurgiu, România \\
\hline V13 & Galben-mare Otiman & Sviniţa, CS, România \\
\hline V14 & Viscool & Italia \\
\hline V16 & Zona Parcul Tineretului & București, România \\
\hline V17 & Olimpia & Timișoara, România \\
\hline V18 & Smochin negru & Ploiești, Prahova, România \\
\hline V21 & Str. Părintele Stăniloae & București, România \\
\hline V24 & Facultatea de horticultură 1 & București, România \\
\hline V26 & Str. Dr. Constantin & București, România \\
\hline V28 & Brazi & Brazi, Prahova, România \\
\hline V34 & Rot negru Otiman & Svinița, CS, România \\
\hline V36 & Bifera Bianca & Italia \\
\hline V37 & Natauwa & Italia \\
\hline V38 & Fig. Miele nero & Italia \\
\hline V39 & Fig. Bianca nero & Italia \\
\hline V40 & Fig. Awitato & Italia \\
\hline V41 & Fântânele Ph & Kerkuk, Irak \\
\hline V42 & Irak 1 & Kerkuk, Irak \\
\hline V44 & \\
\hline V45 & \\
\hline & Irak 3 & \\
\hline
\end{tabular}

ornamental and fruit tree. At the Bucharest Faculty of Horticulture recently, fig genotypes have been collected from different places around Romania, propagated and studied.

This paper presents the first results regarding the characterization of some Romanian and Iraqian fig genotypes. After the identification of as many as possible local fig genotypes, a distribution wide map in Romania will be made. By analysing different plants/fruit parameters the best genotypes will be proposed to be planted in the future.

\section{MATERIALS AND METHODS}

Cuttings from different figs genotypes and different regions of Romania were collected and rooted. One genotype from Iraq was also included in the trial, in order to test its adaptation to the local Romanian growing conditions.

After rooting the new obtained plants were planted in pots and grown under controlled conditions (cold glasshouse) for a year. By using the mother plants and/or the new propagated plants, several measurements and determinations were done in order to characterize each genotype.

From all the formed leaves grown in the first year, four average looking were studied and measured with WinFolia scanner and software, while fruits were observed, measured and total soluble solids was determined by refractometer.

Table 1 presents the different genotypes identified.

From each genotype, leaves were analysed with WinFolia, a computer image analysis system 


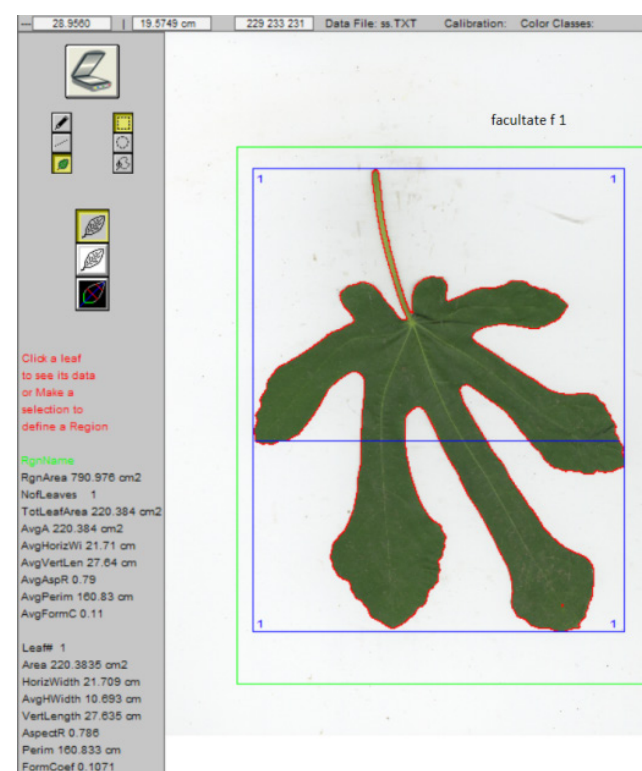

Fig. 1. V24 genotype scanned with WinFolia software

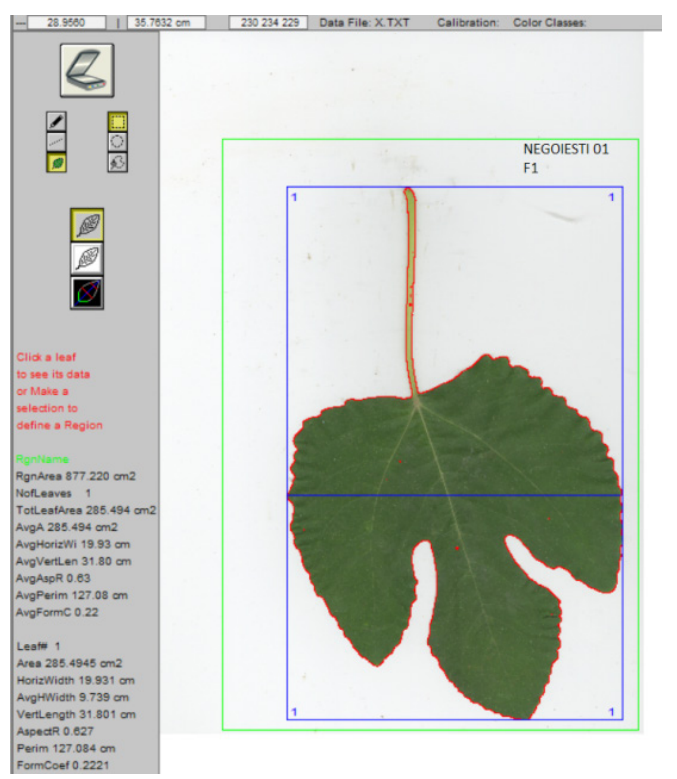

Fig. 3. V3 genotype scanned with WinFolia software

that performs morphological measurements. The system is composed by a scanner Epson Expression $11000 \mathrm{XL}$ and a software designed for measuring the leaf area.

The principal leaf analysed parameters were: total area, perimeter, horizontal width, vertical length and shape coefficient $(4 \pi \mathrm{A} / \mathrm{p} 2, \mathrm{~A}=$ leaf area and $p=$ leaf perimeter) (Win Folia, 2015).

Fruits were measured with digital callipers and weighted with technical balance Partner PS1200.R2. For each genotype some morphological
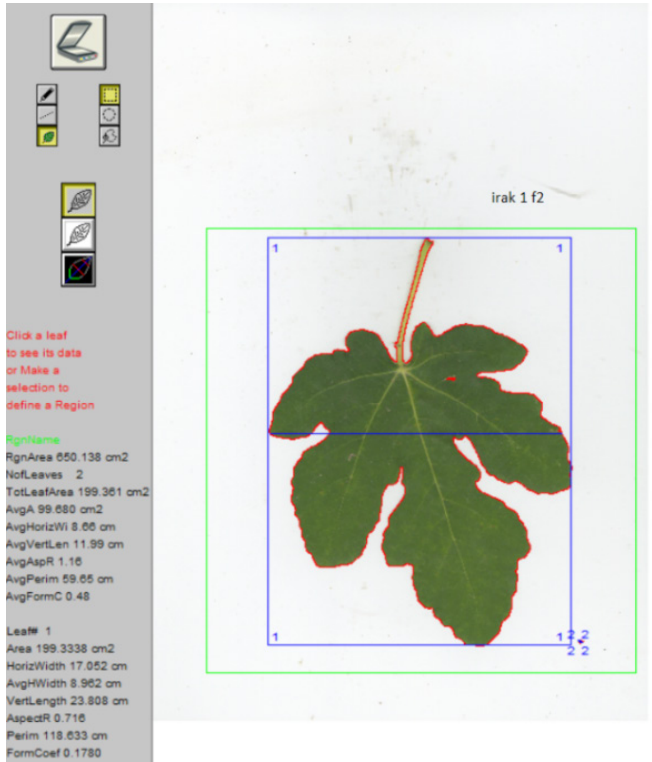

Fig. 2. V42 genotype scanned with WinFolia software
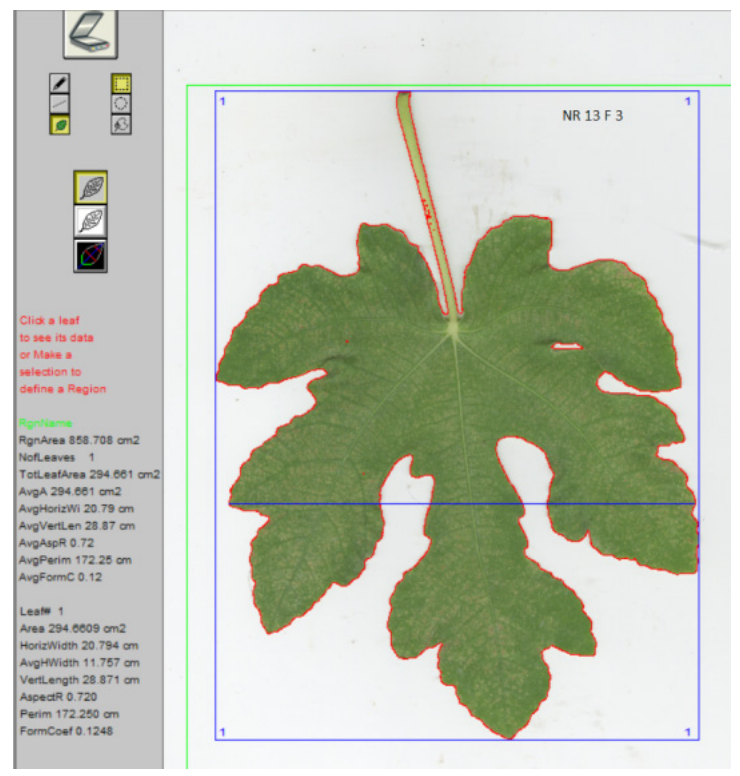

Fig. 4. V13 genotype scanned with WinFolia software

parameters such as fruit weight, length, width, ostiole diameter; peduncle length, diameter and shape were measured; fruit skin colour, rust and side cracking were also determined (Fig. 6-7). Total soluble solid content were determined with Kruss digital refractometer DR301-95.

\section{RESULTS AND DISCUSSIONS}

From each genotype were collected and analysed four leaves per plant scanned with WinFolia software (Fig. 1-4) 
Tab. 2. Leaf analysis of studied fig genotypes

\begin{tabular}{ccccc}
\hline Genotype & Length $(\mathrm{cm})$ & Width $(\mathrm{cm})$ & Perimeter $(\mathrm{cm})$ & Shape coefficient \\
\hline V1 & 28.51 & 8.98 & 140.70 & 0.14 \\
\hline V2 & 30.09 & 10.92 & 138.60 & 0.16 \\
\hline V3 & 32.02 & 9.17 & 126.07 & 0.22 \\
\hline V4 & 32.25 & 8.14 & 115.67 & 0.24 \\
\hline V5 & 30.62 & 10.16 & 123.74 & 0.23 \\
\hline V9 & 15.90 & 15.10 & 124.05 & 0.20 \\
\hline V11 & 28.27 & 9.84 & 127.40 & 0.19 \\
\hline V13 & 29.60 & 9.72 & 97.78 & 0.22 \\
\hline V14 & 24.93 & 9.27 & 111.71 & 0.21 \\
\hline V16 & 19.83 & 13.64 & 138.61 & 0.24 \\
\hline V17 & 23.49 & 9.59 & 132.23 & 0.14 \\
\hline V18 & 26.16 & 7.66 & 110.71 & 0.19 \\
\hline V21 & 16.3 & 17.5 & 133.22 & 0.15 \\
\hline V24 & 27.44 & 9.60 & 158.01 & 0.101 \\
\hline V26 & 30.60 & 10.09 & 169.37 & 0.10 \\
\hline V28 & 20.61 & 8.11 & 114.65 & 0.13 \\
\hline V34 & 16.18 & 6.25 & 76.65 & 0.18 \\
\hline V36 & 26.56 & 9.13 & 144.09 & 0.12 \\
\hline V37 & 23.92 & 8.95 & 102.74 & 0.23 \\
\hline V38 & 21.87 & 10.00 & 92.85 & 0.78 \\
\hline V39 & 23.68 & 9.80 & 107.29 & 0.22 \\
\hline V40 & 22.40 & 9.40 & 96.05 & 0.28 \\
\hline V41 & 21.41 & 8.80 & 133.09 & 0.11 \\
\hline V42 & 24.93 & 9.27 & 111.71 & 0.21 \\
\hline V44 & 27.37 & 8.87 & 118.81 & 0.19 \\
\hline V45 & 24.63 & 8.47 & 117.77 & 0.16 \\
\hline & & & & \\
\hline & & & & \\
\hline & & & & \\
\hline
\end{tabular}

Area $(\mathrm{cm} 2)$

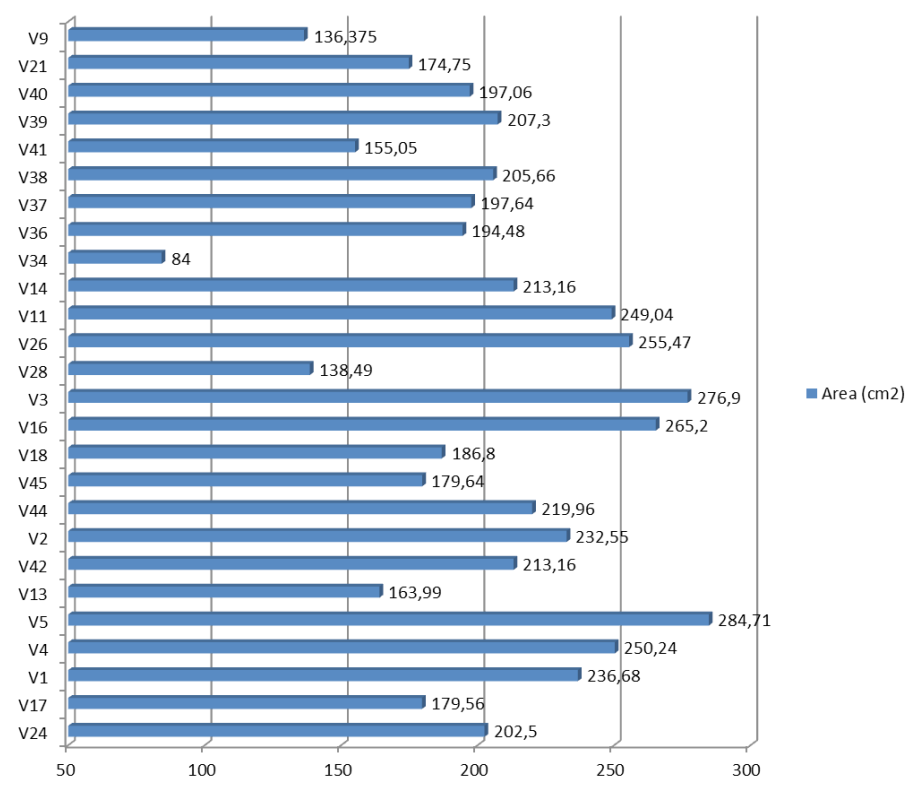

Fig. 5. Fig genotypes leaf area 


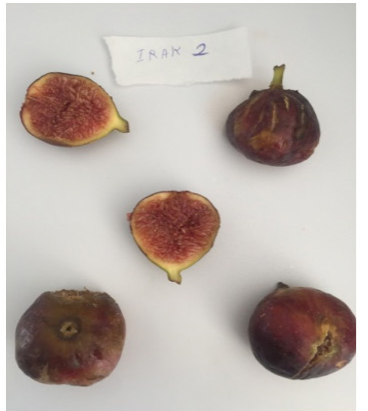

a.

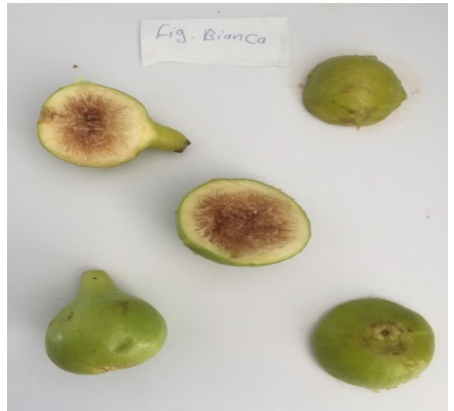

b.

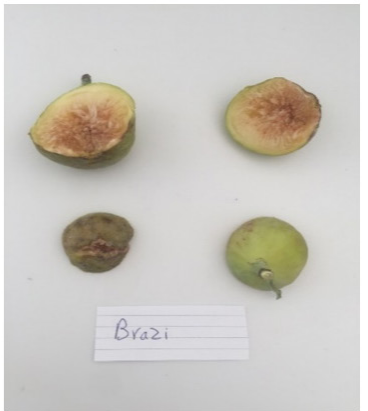

c.

Fig. 6. Fig fruits (a - V55, b - V36, c - V28)

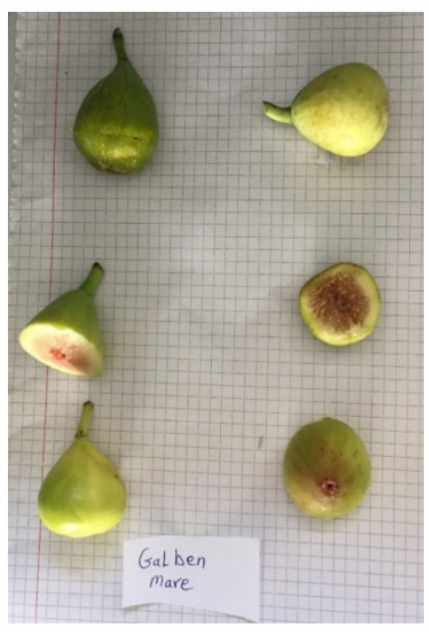

a.

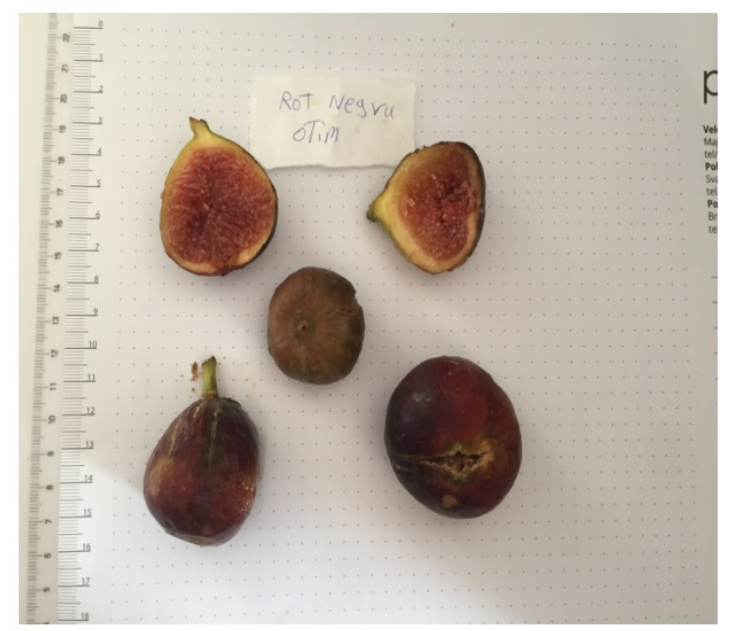

b.

Fig. 7. Fig fruits $(a-V 13, b-V 34)$

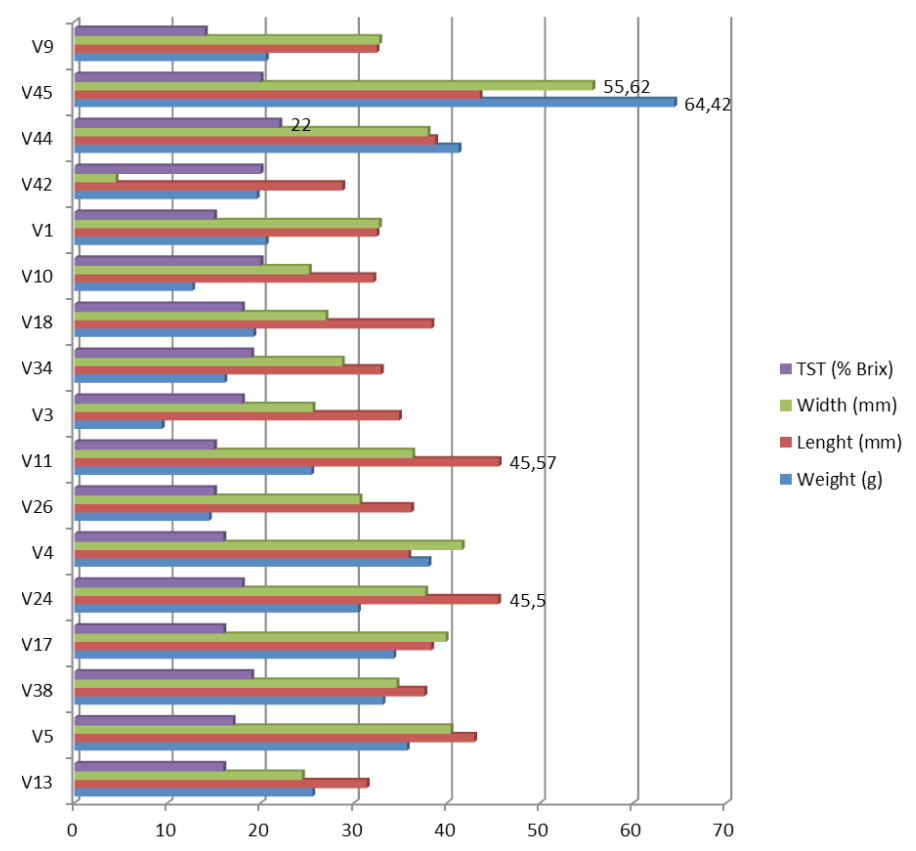

Fig. 8. Fig fruit parameters 
Leaf shape varied from a single to three, five and seven lobes respectively.

Leaf length varied from $15.9 \mathrm{~cm}$ (V9) to 32.25 $\mathrm{cm}$ (V4) and width varied from $6.25 \mathrm{~cm}$ (V34) to $17.50 \mathrm{~cm}$ (V21). Leaf perimeter varied from 76.65 cm (V34) to $169.37 \mathrm{~cm}$ (V26) (Tab. 2).

Total leaf area varied from $84.21 \mathrm{~cm}^{2}$ (V34) to $284.71 \mathrm{~cm}^{2}$ (V5) (Fig. 5).

Fruit colour varied from light green, yellow, brown green to dark mauve. Pulp internal colour varied from pink, amber, red to dark red (Fig. 6-7).

Fruit average weight varied from $9.39 \mathrm{~g}$ (V3) to $64.42 \mathrm{~g}$ (V45). Fruit length varied between 28.77 $\mathrm{mm}$ (V42) to $45.57 \mathrm{~mm}$ (V11) and width between $4.43 \mathrm{~mm}$ (V42) to $55.62 \mathrm{~mm}$ (V45). Total soluble solid content measured varied from $14 \%$ (V9) to 22\% (V44) (Fig. 8).

\section{CONCLUSIONS}

The analysis of fig genotypes showed an important genetic variability for all the analysed characters. According to leaf analyses, we can identify some categories of leaf typologies. The observations are in progress and will continue for the introduced biotypes and supplementary observations will be made for the ripening time. The collected biotypes are planted in 2017 and studied in four testing plots at Pietroasa Viticulture and Wine Processing Research Station, Dăbuleni Research Station, Faculty of Horticulture and Svinița Village, Mehedinți.

\section{REFERENCES}

1. Bandelj Mavsar D, Bohanec B, Bucar Miklavcic M, Butinar B, Javornik B, Jakse J, Podgornik M, Prgomet Z, Skrt A, Tomazic I, Vrhovnik I, Valencic V (2008). The Common Fig (Ficus carica L.) in Istria, Publishing House Annales, Koper.

2. Gâlă R, Velcea M, Stănică F, Diaconescu O (2003). Influenţa apei Pi asupra înmulţirii in vitro a smochinului (Ficus carica L.), Simpozionul internaţional „Apa un miracol” Ediţia a III a, Bucureşti 25-26 iunie (pp. 24-25).

3. Ghena N, Braniște N, Stănică F (2010). Pomicultură generală, Ed. Invel Multimedia, p.128.

4. Hoza D (2000). Pomologie. Editura Prahova, Ploiești, ISBN 973-99268-3-5.

5. Hoza D (2000). Cultura arbuştilor fructiferi. Idei de afaceri, Rentrop-Straton, Bucureşti, ISBN 973-9495-96-6.

6. Hoza D (2001). Cultura căpșunului, semiarbuștilor și arbuștilor fructiferi. Editura Elisavaros, București, ISBN 973-98601-9-2.

7. Stănică F., Braniște N.(2011). Ghid pentru pomicultori, Ed. Ceres, p. 169.

8. Stănică F., Peticilă G.A. (2011), Înfiinţarea plantaţiilor pomicole. Editura Valahia University Press, ISBN 978606-603-033-5 pg. 226.

9. Stănică F, Gâlă R, Diaconescu O (2003). Cercetări privind înmulţirea in vitro a smochinului (Ficus carica L.), Lucrări ştiinţifice, Facultatea de Horticultură, UŞAMV Iaşi.

10. Stănică F (2000-2008). Înmulţirea in vitro a unor plante pomicole: măr, gutui, smochin, cireș.

11. WinFolia for Leaf Analysis, (2015), Regent Instrument Canada Inc., Technical Support. 